\title{
What Did SAP Change? A Market Shaping Analysis
}

\author{
Burak Erkut \\ Lecturer, Chair of Economic Policy and Economic Research, Faculty of Business and Economics, Technische \\ Universität Dresden
}

Fellow, Institute for Research in Economic and Fiscal Issues (IREF)

\begin{tabular}{|c|c|}
\hline & ABSTRACT \\
\hline $\begin{array}{l}\text { Keywords: } \\
\text { Market Shaping, Product } \\
\text { Innovation, ERP Software } \\
\text { Market }\end{array}$ & $\begin{array}{l}\text { The market for enterprise resource planning (ERP) software was analysed in the } \\
\text { contexts of computer science, business models, sociology and history. However, the } \\
\text { impact of SAP which has driven the ERP software market with its product innovation } \\
\text { was not analysed in the framework of market shaping. Particularly, a new direction } \\
\text { within marketing which aims to re-connect it to markets can be an interesting point of }\end{array}$ \\
\hline $\begin{array}{l}\text { Received } \\
19 \text { October } 2017\end{array}$ & $\begin{array}{l}\text { departure for the analysis since the way ERP software shaped the markets has similar } \\
\text { impacts with the way internet shaped the markets. Using a framework based on three }\end{array}$ \\
\hline $\begin{array}{l}\text { Received in revised form } \\
24 \text { May } 2018\end{array}$ & $\begin{array}{l}\text { market shaping effects, the results suggested that SAP's impact was mainly on agency } \\
\text { costs, transaction costs and network effects. These three points suggest a similarity to }\end{array}$ \\
\hline $\begin{array}{l}\text { Accepted } \\
26 \text { May } 2018\end{array}$ & the market shaping impact of internet economics. \\
\hline
\end{tabular}

\section{Correspondence:}

Burak.Erkut@tu-dresden.de

What did the firm "Systems, Applications \& Products in Data Processing" (SAP) change with its product innovation and why is this change important from the perspective of economics, markets and market shaping? Enterprise resource planning (ERP) software is aimed at businesses for organizing their own business processes, with SAP being globally the biggest shareholder with a market share of $20.3 \%$, and practically the pioneer software firm that shaped the market of the "ERP systems" in the contemporary terminology (Panorama Consulting Solutions, 2016). Therefore, the first question can be answered by the fact that the 
emergence of ERP software market and SAP's role in this emergence process changed the way of decision making processes in firms by providing them a tool to get a better and up-todate overview of their own business. The second question can be answered with the volume of the global market for ERP software, \$25.4 Billion in 2013 (Columbus, 2014) and expected to reach $\$ 49.50$ Billion by 2020 (Market Research Engine, 2017). Although the emergence of the ERP software market was analysed from the perspectives of computer science, business models, sociology and computer history, it lacks a framework to understand its impacts on market shaping.

The differentiation between invention and innovation is a matter of the economic meaning and use of the new knowledge, i.e. its market relevance. The market relevance of an innovation can be analysed in terms of the ways it shapes markets by creating different economic impacts. To keep the competitive advantage of an economy, the role of innovation is considered as an important factor of influence (Erkut, 2016a). A group of scholars of marketing and market sociology propose that by focusing more on the emergence stage of new market segments, and by gaining new insights from the market, emergence stage can be relevant for the marketing science, especially since marketing is associated with shaping markets (Araujo, Finch, \& Kjellberg, 2010). In a sense, new product development, launch, promotion, distribution and recognition can be described as the relevant stages of marketing innovation, which is an important aspect of strategic management (Ostrovskaya, Yurev, Stepicheva, \& Denisov, 2014). The relevance and the importance of the marketing of innovations for strategic management issues can be explained in terms of creating and/or keeping a competitive advantage for firms based on innovations (Erkut, 2016a). Ostrovskaya et al. (2014) propose a number of interactions between the modern firm and its environment in order to integrate marketing innovation into strategic management.

Given market acceptance and market relevance of new, the innovative ideas and knowledge, and relevant target groups inside and outside the firm can act as accelerators of the stages of the marketing of innovations. Since the emergence of the concept of lead users has been in the focus of the innovation research (Von Hippel, 1986). They are ahead of the market in terms of their needs, and in most cases are those who develop their own technological solutions to satisfy their own needs, finding relevant target groups outside the own firm to generate new knowledge in form of new technologies and new services. This has been on the agenda of the co-development of products by developer teams and customers (Anderson \& Crocca, 1993), hearing the voice of the customers (Griffin \& Hauser, 1993) and finally for opening the innovation process to inflows and outflows of knowledge, described as open innovation by Chesbrough (2003). This stream of research points out to the fact that the generation of new knowledge requires dynamics that go beyond the internal dynamics of the organizations and requires interactions with the environment of the organization to profit for the strategical direction of an organization (Mintzberg, Lampel, Quinn, \& Ghoshal 2013; Ostrovskaya et al., 2014), but needs to utilize the unutilized ideas within the organization (Chesbrough, 2003).

The evolution of ERP software market goes back to a product innovation introduced to the market by five German former IBM employees who established their own firm (SAP). The evolution of business integration concepts is a key factor in understanding today's ERP 
software market which evolved from material requirements planning and manufacturing resource planning (Klaus, Rosemann, \& Gable, 2000). It started with the aim to have more precise calculations for needed materials and then to have a more efficient manufacturing process - the more profitable these steps were, the more interest emerged for applying it to the enterprise as a whole (Klaus et al., 2000). According to a study conducted by Panorama Consulting Solutions between September 2013 and February 2016, the global market shares of the top five ERP vendors are as follows (Panorama Consulting Solutions, 2017): SAP 20.3\%, Oracle 13.9\%, Microsoft 9.4\%, Infor 7.4\% and Epicor 3.5\%. Software products of the ERP target building digital infrastructures and their evolution continue towards cloud computing. In addition to being the biggest shareholder of the ERP software market, SAP is also the largest European software firm with annual revenue of $€ 22.07$ billion (McDermott, 2017).

Based on this background information, the research question formulated at the beginning of this article can be re-formulated as follows: What are the market shaping impacts of the product innovation introduced by SAP and resulted in the emergence of today's ERP software market?

To answer this question, the author provides an overview of SAP's product innovation going back to 1972-1973 in Section 2. Section 3 provides a market shaping analysis of this software program's impacts, listing the factors of success. Section 4 provides a discussion and makes some concluding remarks.

\section{SAP's Product Innovation}

The role of SAP as the market leader in the ERP software market goes back to the product innovation made by its founding team in 1972-1973. Founded in Mannheim, Germany, SAP introduced a standardized business application software for integrating business processes in real-time (Leimbach, 2010) for the first time in computer history - at a point of time where the computer industry in USA was more developed than that of Germany (Lehrer \& Behnam, 2009). In order to precisely understand the meaning of this product innovation, it is important to understand the evolution of enterprise systems, i.e. the applications that help to operate an enterprise. Starting from 1960s onwards, single-function systems were created in different fields such as customer services, finances, Material Requirements Planning (MRP), master production scheduling and similar fields of application (Worster, Weirich, \& Andrea, 2011). These single-function systems capturing business processes of a certain aspect of a business did not suddenly appear, but rather evolved from the manual work of handwritten books to more automated systems; some examples include the evolution from the handwritten accounting ledgers to the financial system of the General Ledger, and the evolution from the Bill of Materials books and tub files to the more automated MRP, and from that to the Manufacturing Resources Planning (MRP II).

Out of these single-function systems, the former IBM Germany employees Hasso Plattner, Dietmar Hopp, Claus Wellenreuther, Klaus Tschira and Hans-Werner Hector suggested that these single functions should be integrated into one, "where the logical implications of each action taken in a business were automatically, and for the most part simultaneously, posted to each of the areas affected" (Worster et al., 2011, p. 70). In other words, the product 
innovation of SAP introduced a software program comprising different business applications such as accounting, finance and production in order to help to operate an enterprise in the 1970s (Lehrer \& Behnam, 2009). According to Lehrer and Benham (2009), at this point of time the software developers from the USA did not see the practicality of such a software program, and it was a favourable nature of the demand in Germany, which gave a chance for the development of this software program.

In addition to the integration of business processes, another important aspect of the product innovation of SAP is the standardization aspect. Until the introduction of the product innovation of SAP, business application software programs were customized, i.e. the market was dominated by individual software programs which were developed by either consultants or external software firms according to the needs of the customer. However, the co-founders of SAP noticed that the business processes of customers from different sectors were very similar (Meissner, 1997; Wolf, Geiger, Benlian, Hess, \& Buxmann, 2008) and instead of programming special software for each customer, they aimed to have standard software for all customers. Lehrer and Benham (2009) posited that the highly standardized business processes in Germany can be a key feature to the pattern recognition of SAP's co-founders. Lehrer and Benham recognized the similarities in the patterns of business processes in different firms across different contexts and were able to translate these needs into a technological product, even though the German software market was not as developed as that of USA and the technological frontiers did not initially allow such a development (Leimbach, 2010).

The third aspect that constitutes the product innovation of SAP is the real time data processing property. Until SAP introduced its product innovation, the method of data processing was the batch principle, where punch cards were used to process data (Leimbach, 2010). The update of firm data was only possible after a long process of manual data procession, which was open to errors (Mormann, 2013). Even though IBM worked on to integrate the data processing of firms into a single software framework since 1950s, the developed software Bill of Materials Processing (BomP) and Production Information and Control System (PICS) failed in the market due to hardware limitations (Müller, 2010). Hence, the batch principle continued until SAP's product innovation which involved real time data processing - in today's words, "online” data processing, which meant that "there was a single version of the truth” (Worster et al, 2011, p. 70). In terms of Worster et al. (2011), “(...) a quantity of inventory that the inventory control system showed as in stock could be automatically multiplied by the standard cost stored in an accounting record (...), and stored on the General Ledger, and at the same time”. Plattner, Scheer, Wendt, \& Morrow (2000) gave an example of how month-end closings became meaningless after SAP's product innovation, simply because the real-time data processing allowed a continuous bookkeeping without a need to wait until the end of the month to check for the account information of a firm.

System R had a one-tier architecture where database, application and presentation were installed in a single system (Markandeya and Roy, 2014). The software of SAP was compatible with IBM until 1977; from then SAP also designed its software program in a way to be compatible with Siemens (Leimbach, 2010). Not only were the SAP co-founders 
socialized in IBM, but also IBM mainframe computers had a dominating role in the German software market of the era (Leimbach, 2010). According to Müller (2010), the development of the SAP software Material Information and Accounting System (MIAS), which was the first version of SAP's software program R, cannot be explained by only pointing out to the technological opportunities or limitations in IBM. Rather, the SAP co-founders' technological vision is an important factor in the development of the software program, whereas the stand of hardware was rather a restrictive factor in this development.

Wolf et al. (2008) analyzed SAP's evolution in terms of its value chain. An important indication regarding the first years of SAP is to observe research and product development in two different processes in the value chain instead of one. Whereas the research phase comprised the generation of ideas, the feasibility analysis and the structured planning. The development phase consisted of the more specific development of the product such as use of codes to develop the software and the test phase. In addition to research and product development, documentation and marketing were the other two phases of what the authors call the product focus of the firm. In addition to the product focus, there was also a service focus in the value chain consisting of consulting, implementation, training and maintenance. To sum up, the following observations can be done on the nature of SAP's product innovation: (i) SAP introduced a new software program which was integrating business processes for sales, materials management and accounting, (ii) which was standardized for businesses and (iii) which allowed entering data in real-time (Leimbach, 2010). Starting with a prototype for a single customer (where they were not sure, whether they would continue to sell the programme), SAP co-founders learned with each installation and shaped a new market segment (Meissner, 1997).

\section{A Market Shaping Analysis}

What are the market shaping impacts of SAP's product innovation? This question is relevant for understanding why this certain product innovation, this new technological knowledge, found acceptance in the market. The market shaping impacts of the introduction and implementation of the software programme can be analysed within the framework of Dholakia, Dholakia, and Park (2002). This framework analyses infrastructure innovations and their market shaping impacts, which is applicable to ERP (and by extension to the predecessors of ERP) since implementing an ERP system is accepted as a digital organizational infrastructure innovation (Clagett \& Berente, 2012) going back to a product innovation (Müller, 2010). The market shaping impacts of this product innovation and the corresponding emergence of a new market segment can be described with three effects.

\section{Agency Costs}

Diverging interests of the owner/manager of an organization and the agents who carry out tasks for the owner/manager may lead to agency costs (Dholakia et al., 2002). Current ERP systems may lead to an increase in the performance of firms. Hitt, Wu, \& Zhou (2002) found that financial markets react positively to the firms which are adapting ERP systems. The rewarding is not due to the implementation itself, "but the value of changed organizational structure, business process redesign, training, and education of the workforce, and other 
organizational assets that are not typically captured on the balance sheet” (Hitt et al., 2002, p. 89). Prior to the introduction of SAP's product innovation, the activities of a firm could be observed only with large delays with possibly wrong information due to the problems with data processing and due to the fact that the available software programs were single-function ones (Farhoomand, 2007). The difference between the real stand of information and the information that can be given by data processing was a crucial factor associated with entering data in real-time, which was made possible with SAP's System R for the first time. Hence, after the introduction of SAP's System R, agency costs were able to be reduced by two means: A more accurate coordination and observation of the operations of a firm, and the enabling of a quicker decision process. These two ways of cost reduction can be seen in information technologies in general (Dholakia et al., 2002).

\section{Transaction Costs}

Transaction costs are "costs of acquiring the knowledge which is necessary to make transactions or the costs of making arrangements to counteract the irremediable lack of knowledge about the future” (Loasby, 2002, p. 76). Even though from today's perspective it is not thinkable, prior to the introduction of SAP's product innovation, the decision makers in a firm could not say, e.g., the current number of goods in their warehouse, because the data available was only giving the stand of information from a few days to a few weeks before. Hence, there were higher costs of transaction due to the high uncertainty of a situation what lacked a "single version of the truth" (Worster et al., 2011, p. 70). In addition, not only the external communication with customers was involved with high transaction costs, but also the internal communication between the departments of the firm - simply because two different departments could not see what each other was doing due to the lack of an integrated overview of the business processes of the firm. The initial form of SAP's software programme consisting of three modules (sales, materials management, and accounting) give an overview of business processes with accurate information processed in real-time. Hence, the transaction costs between the departments of the firm were reduced because each department would know what another department was doing and provided that these actions were related to each other, or had impacts upon each other; as a result, it can be understood how big the impact of such a software program was.

\section{Network Externalities}

Infrastructure technologies are considered as network technologies linking people and institutions where "the economic benefit of the network derived by each linked node increases as the size of the network expands” (Dholakia et al., 2002, p. 38). In case of more organizations joining the ERP system, cost efficiencies come into existence for present organizations, since "the zero or very low marginal costs for information reproduction reduces the high ERP implementation costs" leading to positive network externalities (Huang, Wang, Yu, \& Chiu, 2004, p. 691). In fact, SAP co-founders' initial observation of similarities in business processes of different firms (Meissner, 1997) can be interpreted as a move towards making use of network externalities - since the absence of a standardized business software led the programmers to create a new programme for every new customer 
every time, even though the complexities of business processes that emerged from 1960s onwards were challenging customized software development (Leimbach, 2010). Prior to the introduction of SAP's System R, firms were either using their own software programmes developed specifically for them by external software firms, or were developing their own software programmes with the help of consultants, which started to change by the end of 1960s, when the tendency for standardized software programmes emerged due to reasons of practicality (Leimbach, 2010). Even though other firms also started to offer standardized software programmes, it was SAP which was the pioneer firm offering an integrated, standardized business software programme enabling real-time data processing. Therefore, the network externalities were used not only with a merely standardized programme, but with a programme integrating different business processes resembling similar structures in firms, and enabling the common wish of all firms around that time - getting rid of the batch principle, and opening the way to the "single version of the truth" (Worster et al., 2011, p. 70).

\section{Factors of Success}

A successful product innovation pioneers the emergence of a new market segment. This emergence does not occur with an external shock, but rather with the imagination and actions of human beings (Witt, 1998, 2007). It is not only the technological knowledge is relevant for this process, but also how this technological knowledge is embedded in the organization that is shaping the market with it - what Witt $(1998,2007)$ calls this as business conceptions. SAP's co-founders introduced their standardized, integrated business software in real-time at a point of time where it was the first of its generation. Looking at the current situation, it has been forecasted that in a couple of years, the market segment shaped by SAP will have a market volume increase by $\$ 49.50$ Billion (Market Research Engine, 2017), where SAP is the biggest shareholder. A number of factors seem to be effective in SAP's success (Lehrer \& Benham, 2009; Leimbach, 2010; Meissner, 1997; Müller, 2010; Nambisan, 2002): Nambisan (2002) recognizes that (i) technology leadership and (ii) investments for building domain knowledge influenced the success of SAP, whereas Lehrer and Benham (2009) propose that (i) the cumulative diffusion of the technology and (ii) increasing versatility of the software program allowing it to be very compatible in a big range of contexts were both decisive. On the other hand, Leimbach (2010) noted that SAP's (i) initial strategy of writing a software program for the IBM hardware, (ii) relationships with pilot customers and the codevelopment of the software program with them, (iii) internationalized customers, (iv) relationships with consulting and auditing organizations building a bridge between SAP and its customers, (v) financial structure and (vi) organizational structure can be considered as the factors of success.

Müller (2010) observes SAP's development from the perspective of technology push and actor-network theory, and states that (i) the technological opportunities are a key to the success of SAP. However, he mentions that technological determination alone is not sufficient to explain the success of the product innovation; especially how economic actors' behavior and interactions with their environment can influence the product innovation cannot be answered within his framework. The author expands the analysis within the actor-network 
theory to emphasize the role of (ii) how SAP made use of its network of contacts to become successful. In addition, (iii) unbundling of hardware and software as well as (iv) the competent team of SAP co-founders and (v) SAP being a virtual firm can be added as further factors of influence. The business model of SAP is on the agenda of Antero (2015), who focuses on the evolution of the business model of SAP over time, and concludes that the use of technology for solving customers' problems can be a key aspect of SAP's success.

These results indicate similar perspectives regarding the success factors: The co-founders were all former employees of IBM, and were able to observe different business processes of different clients of IBM, they financed themselves for a very long period of time, they were a heterogeneous team with different competencies, their geographic location was a plethora of international customers which led them to use English in their programming procedures, they were the first ones introducing a particular product innovation to the market, they used a word-of-mouth strategy to build on a previous innovation of a team member known in the region, and they managed to achieve a technological success, which IBM itself failed to achieve for more than 20 years, to mention only a few.

\section{Discussion and Conclusion}

Since finding an innovative idea, establishing an enterprise, designing a business conception and therefore shaping the market are all very individualistic actions, they do not necessarily need to be pre-determined - they all have the subjective nature of knowledge in common. "Of many ideas about technological and commercial activities which may be developed by many people, only a tiny fraction is actually turned into a venture in the form of a multi-person firm” (Witt, 1998, p. 175), which implies a selection process. In general, processes influenced by human agents suffer from simplifying stylizations (Lehmann-Waffenschmidt, 2010) and one of them can be, as suggested above, the perspective of a success story. In other words, these simplifying stylizations may include product innovations and market shaping processes as well, even though these concepts cannot be actually pre-defined, pre-determined stories designed to be successful, since they "begin as gleams in the eyes of individuals" (Sarasvathy, 2001, p. 261) and are contingent to environmental, social, technological conditions.

A review of the literature on the role of users or customers in innovations show that the concept has evolved from a pure technological perspective (Anderson \& Crocca, 1993; Griffin and Hauser, 1993; von Hippel, 1986) to the role of social interpretation of technologies. Tuomi (2002) proposed that innovations require a change in social practices and interpretations of technologies. Tuomi (2002) noted that "the heroic individual innovator is not a good model when we try to understand the evolution and development of technology" (p. 6). This not only points out to the fact that the relation between a product innovation and its success is not a direct relation without any alternative possible events leading to an unsuccessful outcome, but also provides a new perspective of the local availability of the subjective knowledge and its social context as the decisive factor behind innovations or how a certain invention gains an economic meaning and shapes the market. Especially meaningful in this context is the dimension of irreversible time, which, once a product innovation emerges, is the distinctive factor between the past (before the emergence of the product 
innovation) and the future (after the emergence of the product innovation) (Kirstein, 2016). Based on the irreversibility of the historical time, the observation of a product innovation at the point of time $t$ and the success of the product innovation at the point of time $t+i$ and the analysis of these notions in an open loop evolving environment, one may fall into the trap of post hoc ergo propter hoc. The fact that the success of the product innovation occurs after its emergence only means that these two events occur after each other over time, but the event occurring later in time does not need to be a necessary consequence of the event that occurred earlier in time. If this is not recognized, often myths emerge as "success stories" that can lead to an irreversible way of thinking in terms of innovation management (Christensen, 2016; Lehmann-Waffenschmidt, 2004). Even though how a product innovation becomes successful or not depends on a number of circumstances that can be characterized as contingent (Tidd \& Bessant, 2014), i.e. having at least one other alternative, that is "not impossible, but not necessary" (Lehmann-Waffenschmidt, 2010, p. 482).

Contingency of an event or events may be seen in counterfactual thinking as an application, where a counterfactual is defined as "an ex-post constructed non-factual (essential) characteristic of a factual state” (Lehmann-Waffenschmidt, 2010, p. 484). It can be used to explore historical processes over time and their causal relations. Likewise, in case of an alternative factual analysis where two or more alternative factual processes are proposed as comparative processes (Lehmann-Waffenschmidt, 2010). Counterfactual analyses may be organized on two levels; whether two alternative process realizations occur synchronically or consecutively, and whether there are structural (system-generated) alternative process realizations or situative (those generated by decision makers), leading to a $2 \times 2$ matrix of representation. An example in SAP's case is the strategies of SAP co-founders and IBM during this era, focusing on developing the software programme against focusing on hardware production respectively - a case of situative counterfactual regimes occurring synchronically. A system generated issue is the economic development in West Germany after the Second World War from a National Socialist regime to a regime of social market economy, opposing to the Morgenthau Plan by the Allies proposing an agricultural economic structure (Casey, 2005) which would reduce the economic importance of Germany. The West German economy became a new centre of attraction for German and foreign industrial firms, with its regions such as the Rhine-Neckar Metropolitan Region, out of which SAP and its network of customers emerged, leading to its international expansion (Erkut \& Kaya, 2017). Defining contingency as "not impossible, but not necessary" (Lehmann-Waffenschmidt, 2010, p. 482) implies that past events have at least another alternative possible event, which was not realized, but could have been realized. The concept of contingency can be applied to the concept of entrepreneurial discovery if it is also seen as in the midway between chance and necessity. According to Kirzner (1997), entrepreneurial discovery can be defined as "midway between deliberately produced information in standard search theory, and that of sheer windfall gain generated by pure chance” (Kirzner, 1997, p. 72).

Given SAP's business history as a point of departure, Audretsch and Link (2012) focus on the so called knowledge filters which may block investing into ideas and knowledge to turn them into commercialized artefacts. Hence, even though the research on innovation focuses more on the role of the sources of ideas from the outside of the organization as well as the 
unutilized ideas within the own organization, a knowledge filter may still prevent the transformation process of an idea to an artefact, because "no one can know what outcome or value will be generated from pursuing and implementing new ideas" (Audretsch \& Link, 2012, p. 12). This implies the uncertainty regarding the emergence of novelties. These considerations lead to the contingent character of an entrepreneurially driven market process, where "the progress of any particular innovation (...) will depend on a variety of contingent circumstances” (Tidd \& Bessant, 2014, pp. 76-77). The market process is built upon competition as a discovery procedure where "the situation is somewhat like agreeing to play a game based partly on skill and partly on luck" (Hayek, 2002, p. 16). Although the provided framework of Dholakia et al (2002) is a relevant point of departure for understanding the market shaping impact of SAP's product innovation, a new question arises: Is SAP a predefined success story, pre-determined to generate the described impacts, or would its development be different than realized due to the existence of alternative possible events, which could have been realized, but were not? This involves an analysis of causality in the historical process of how the ERP software market emerged.

Introduction of a new product and its economic consequences was the key point of this paper. The research question was SAP's market shaping role in ERP software market, which came into existence with the corresponding product innovation aiming to provide standardized business software in real-time with integrated business processes. The market shaping impact of this development was considered within the framework of Dholakia et al (2002) based on agency costs, transaction costs and network externalities. In a way, the observation of Dholakia et al (2002) regarding the market shaping effects of the internet can be seen as a similar, recurring pattern that already occurred in the context of SAP's product innovation and the way it shaped markets - both have implications on the decision making processes in businesses in this context. An in-depth analysis of SAP's business history can be helpful for understanding both today's ERP software market and the notions of product innovation and market shaping, and the recurrent patterns of this and structurally similar economic processes evolving over time (Lehmann-Waffenschmidt, 2004). The contingent character of the entrepreneurially driven market process was discussed within theoretical considerations by referring to Kirzner (1997) and Hayek (2002). The next goal was set as providing a conceptual framework for the further analysis by considering to the role of perceptions in the generation of new knowledge described by Rizzello (2000) and Erkut (2016b, 2016c, 2017), and that of business conceptions described by Witt (19982007), where he points out to the fact that this has been largely ignored by the Neo Schumpeterian tradition of economics, which focuses mainly on technological knowledge (Witt, 1998) and lacks to integrate marketing knowledge into its framework of analysis (Callon, 2010).

\section{Acknowledgements}

An old version of this article was published in the Proceedings of the $2^{\text {nd }}$ International Conference on Innovation Management, Entrepreneurship and Corporate Sustainability (IMECS) at the Prague University of Economics. I am thankful to the participants of this conference, my PhD supervisor Prof. Dr. Marco Lehmann-Waffenschmidt and two anonymous referees for the feedback. 


\section{References}

Anderson, W. L., \& Crocca, W. T. (1993). Engineering practice and co-development of product prototypes. Communications of the ACM, 36, 49-56.

Antero, M. C. (2015). A multi-case analysis of the development of enterprise resource planning systems (ERP) business practices. Copenhagen: LIMAC.

Araujo, L., Finch J., \& Kjellberg, H. (2010). Reconnecting marketing to markets. Oxford: Oxford University Press.

Audretsch, D. B., \& Link, A. N. (2012). Entrepreneurship and innovation: Public policy frameworks. Journal of Technology Transfer, 37, 1-17.

Callon, M. (2010). Marketing as an art and science of market framing: Commentary. In L. Araujo, J. Finch, \& H. Kjellberg (Eds.), Reconnecting marketing to markets (pp. 224-233). Oxford: Oxford University Press.

Casey, S. (2005). The campaign to sell a harsh peace for Germany to the American public, 1944-1948. History, 90(297), 62-92.

Clagett, J. L., \& Berente, N. (2012). Organizing for digital infrastructure innovation: The interplay of initiated and sustained attention. Paper presented at the $45^{\text {th }}$ International Conference on System Sciences, Hawaii.

Chesbrough, H. W. (2003). Open innovation. The new imperative for creating and profiting from technology. Boston: Harvard Business School Press.

Christensen, C. M. (2016). The innovator's dilemma. when new technologies cause great firms to fail. Boston: Harvard Business School Publishing.

Columbus, L. (2014, May 12). Gartner's ERP market share update shows the future of cloud ERP is now. Forbes. Retrieved from http://www.forbes.com/sites/louiscolumbus/2014/05/12/gartners-erp-market-share-update-shows-the-future-ofcloud-erp-is-now/

Dholakia, N., Dholakia, R. R., \& Park, M. (2002). Internet and electronic markets: An economic framework for understanding market-shaping infrastructures. In N. Dholakia, W. Fritz, R. R. Dholakia, N. Mundorf (Eds.), Global ecommerce and online marketing: Watching the evolution (pp. 31-41). Westport: Quorum.

Erkut, B. (2016a). Structural similarities of economies for innovation and competitiveness- a decision tree based study. Studia Oeconomica Posnaniensia, 5(5), 85-104.

Erkut, B. (2016b). From perceptions to new product development: Product innovation and market shaping. Proceedings of the $12^{\text {th }}$ NeuroPsychoEconomics Conference, p. 34.

Erkut, B. (2016c). Perceiving innovation: Who 'makes' sap labs India and how? South Asian Journal of Business and Management Cases, 5(1), 116-125.

Erkut, B. (2017). Product innovation and market shaping: Bridging the gap with cognitive evolutionary economics. Proceedings of the $13^{\text {th }}$ NeuroPsychoEconomics Conference, p. 45.

Erkut, B., \& Kaya, T. (2017). Knowledge generation for regional competitive advantage. Proceedings of the $18^{\text {th }}$ European Conference on Knowledge Management, 1, 310-317.

Griffin, A., \& Hauser, J. R. (1993). The voice of the customer. Marketing Science, 12, 1-27.

Farhoomand, A. (2007). Opening up of the software industry: The case of SAP. Communications of the Association for Information Systems, 20, 800-811.

Hayek, F. A. (2002). Competition as a discovery procedure. English translation of the 1968 lecture by Marcellus S. Snow. The Quarterly Journal of Austrian Economics, 5(3), 9-23

Hitt, L. M., Wu, D. J., \& Zhou, X. (2002). Investment in enterprise resource planning: business impact and productivity measures. Journal of Management Information Systems,19(1), 71-98.

Huang, M., Wang, J., Yu, S., \& Chiu, C. (2004). Value-added ERP information into information goods: An economic analysis. Industrial Management and Data Systems, 4(8), 689-697.

Kirstein, M. (2016). Von der Ergodenhypothese der Physik zum Ergodenaxiom in der Ökonomik [From the Ergodicity Hypothesis in Physics to the Ergodicity Axiom in Economics]. In J. Kapeller, E. Pühringer, K. Hirte, \& W. O. Ötsch (eds.), Ökonomie! welche ökonomie? stand und status der wirtschaftswissenschaften [Economics! which economics? state and status of the economic sciences] (pp. 71-104). Marburg: Metropolis.

Kirzner, I. (1997). Entrepreneurial discovery and the competitive market process: An Austrian approach. Journal of Economic Literature, 35(1), 269-290.

Klaus, H., Rosemann, M., \& Gable, G. G. (2000). What is ERP? Information Systems Frontiers, 2(2), 141-162. 
Lehmann-Waffenschmidt, M. (2004). Der kontingenztheoretische ansatz zur strukturanalyse verlaufs- und ergebnisoffener wirtschaftlicher prozesse [The theoretical approach of contingency on the structural analysis of non-pre-determined economic processes]. Wissenschaftliche Zeitschrift der Technischen Universität Dresden, 53, 131-136.

Lehmann-Waffenschmidt, M. (2010). Contingency and causality in economic processes -conceptualizations, formalizations, and applications in counterfactual analysis. European Review, 18(4), 481-505.

Lehrer, M. and Behnam, M. (2009). Modularity vs programmability in design of international products: Beyond the standarization-adaptation tradeoff? European Management Journal, 27, 281-292.

Leimbach, T. (2010). Die geschichte der softwarebranche in Deutschland: Entwicklung und anwendung von informationsund kommunikations technologie zwischen den 1950ern und heute [The history of the software sector in Germany: The development and the use of the information and communication technologies between 1950s and today]. Universitätsbibliothek München.

Loasby, B. J. (2002). Knowledge, institutions and evolution in economics. London: Routledge.

Markandeya, S., \& Roy, K. (2014). SAP ABAP: Hands-on test projects with business scenarios. New York: Apress.

Market Research Engine (2017). ERP (Enterprise Resource Planning) Software Market by Verticals (Manufacturing \& Services, BFSI, Healthcare, Aerospace \& Defence and Telecom), by Deployment and by Function (Human Resource, Finance and Supply Chain) - Global Industry Analysis and Forecast 2015 - 2021. Deerfield Beach: Market Research Engine.

McDermott, B. (2017, August 1). Fourth-quarter and full-year 2016 - Preliminary Results Release. Retrieved from https://www.sap.com/docs/download/investors/2016/sap-2016-q4_presentation.pdf.

Meissner, G. (1997). SAP: die heimliche Softwaremacht: Wie ein mittelständisches Unternehmen den Weltmarkt eroberte [SAP: the secret software power: How a medium-size enterprise conquered the world market]. Hamburg: Hoffmann und Campe.

Mintzberg, H., Lampel, J., Quinn, J. B., \& Ghoshal, S. (2013). The strategy process. Essex: Pearson Education Limited.

Mormann, H. (2013). Zur informationstheoretischen und organisationstheoretischen formalisierung von organisation [On the formalization of an organization based on the theories of inofrmation and organization]. In J. H. Passoth, J. Wehner (Eds.), Quoten, kurven und profile [Quotas, curves and profile] (pp. 69- 86). Wiesbaden: Springer Fachmedien.

Müller, T. (2010). SAP im Mikropolis-modell - Analyse des SAP-technikentwicklungspfades auf der grundlage sozialwissenschaftlicher techniktheorien und des Mikropolis-modells [SAP in the Mikropolis model - Analysis of the technological development path of SAP based on the social theories of technology and Mikropolis model]. Hamburg: University of Hamburg.

Nambisan, S. (2002). Software firm evolution and innovation-orientation. Journal of Engineering and Technology Management, 19, 141-165.

Ostrovskaya, V., Yurev, V., Stepicheva, O., \& Denisov, N. (2014). Marketing of innovations as a key area of strategic management of modern enterprise. Review of Applied Socio-Economic Research, 8(2), 124-131.

Panorama Consulting Solutions (2016, August 1). 2017 Top 10 ERP systems rankings report. ERP News, Retrieved from http://www.erpnews.com/downloads/Top-10-ERP-Systems-Report-2017.pdf.

Plattner, H., Scheer, A.-W., Wendt, S., \& Morrow, D. S. (2000). Dem Wandel voraus. Hasso Plattner im Gespräch [Ahead of change: Talks with Hasso Plattner]. Bonn: Galileo Press.

Rizzello, S. (2000). Economic change, subjective perception and institutional evolution. Metroeconomica, 51(2), $127-151$.

Saeed, S., Yousafzai, S., \& Engelen, A. (2014). On cultural and macroeconomic contingencies of the entrepreneurial orientation-performance relationship. Entrepreneurship Theory and Practice, 38(2), 255-290.

Sarasvathy, S. D. (2001). Causation and effectuation: Toward a theoretical shift from economic inevitability to entrepreneurial contingency. Academy of Management Review, 28(2), 243-263.

Tidd, J., \& Bessant, J. (2014). Managing innovation, integrating technological, market and organizational change. Chichester: John Wiley \& Sons Ltd.

Tuomi, I. (2002). Networks of innovation: Change and meaning in the age of the internet. Oxford: Oxford University Press.

Von Hippel, E. (1986). Lead users: Asource of novel product concepts. Management Science, 32(7), 791-805.

Witt, U. (1998). Imagination and leadership - the neglected dimension of an evolutionary theory of the firm. Journal of Economic Behavior and Organization, 35, 161-177.

Witt, U. (2007). Firms as realizations of entrepreneurial visions. Journal of Management Studies, 44(7), 1125-1140. 
Wolf, C. M., Geiger, K., Benlian, A., Hess, T., \& Buxmann, P. (2008). Spezialisierung als Ausprägungsform einer Industrialisierung der Software-Branche - Eine Analyse am Beispiel der ERP-Software von SAP. In G. Herzwurm, M. Mikusz (Eds.), Industrialisierung des software-managements (pp. 153-168). Bonn: Gesellschaft für Informatik.

Worster, A., Weirich, T. R., \& Andrea, F. (2011). ERP systems: A lost opportunity. The Journal of Corporate Accounting and Finance, 22(5), 69-77. 